\title{
Pluricultural competence and VIQTORIA didactic model action in Spanish as a Foreign Language learning systems
}

\author{
Artevic Holgueras Galán ${ }^{1}$, Rocío Santamaría Martínez ${ }^{2}$, Anna Doquin de Saint- \\ Preux ${ }^{2}$ \\ ${ }^{1}$ Department of Spanish, Universidad del Norte, Colombia, ${ }^{2}$ Department of Applied \\ Languages, Universidad Nebrija, Spain.
}

\begin{abstract}
This paper is about a didactic action model named VIQTORIA that intervenes in the process of pluricultural competence acquisition. This work aims to characterize how the postulates of the VIQTORIA model are fulfilled on printed and digital learning systems commonly used in Spanish as a Foreign Language teaching. In order to achieve that, five criteria support the creation of a corpus that classifies 10 learning systems into two categories. The systems are characterized using a diagnostic tool composed of 338 items grouped in 60 parameters, which are distributed in 9 blocks. These blocks capture the four postulates of VIQTORIA: the qualification of the competition, the structuring of the thematic core, the didactic iteration and the operativization of the skills acquisitions device, as well as the constructs that operationalize the pluricultural competence: the Sociocultural Proximity and the Linguistic Posture. The quantitave nature of the diagnostic tool favors the triangulation of results. However, this work is part of a broader heuristic investigation in which the emergence of theory is predominant. Even though the results suggest a considerable room for improvement, the systems analysed, by their digital nature, are involved in constant evolution which could lead to them overcoming the limitations of the traditional teaching-learning paradigm.
\end{abstract}

Keywords: Pluricultural competence; Sociocultural; Linguistics; Learning models; Educational models. 


\section{Introduction}

The CEFR establishes the acquisition of pluricultural competence as a goal for European citizens (Council of Europe, 2001). Integration with the target culture is a challenge for Spanish as a Foreign Language (hereinafter, SFL) learners in an immersion context. Holgueras (2017a) suggests the need to improve their pluricultural competence through a pedagogical innovation. This has guided the design of a didactic action model, called VIQTORIA, which emphasizes aspects traditionally neglected in the teaching-learning processes with the intention of generating competition-acquisition processes: the purpose is the acquisition, the way is the competition.

This work is derived from a heuristic research project, where emerging theory relates to two main constructs, Socio-Cultural Proximity (hereinafter, SCP) and Linguistic Posture (hereinafter, LP), which operationalize the pluricultural competence. The research question is centred on how the VIQTORIA model postulates are fulfilled in the most commonly used SFL learning systems in order to develop SCP and LP. For that purpose, a diagnostic tool has been created to estimate the compliance of the analysed learning systems with the model underlying principles, synthesized in four postulates: the qualification of the competition, the structuring of the thematic core, the didactic iteration and the operativization of the Competences Acquisition (hereinafter, CA) devices.

\subsection{Description of the VIQTORIA didactic action model and his four postulates}

These postulates are more broadly described in Holgueras (2017b), but it seems convenient to summarize them briefly. The first postulate is the result of a process where, in the first place, the concept of competition is reviewed from different approaches (Fulu, 2007; Jiménez, 2012); secondly, the mistakes made in its conceptualization by Deutsch (1949) and Thiess et al. (2004) are identified; thirdly, competition is distinguished from qualified competition in order to solve the "category-mistake" (Ryle, 1949, p. 16), following Shindler (2009), who opposes competition to healthy competition, and Cantador (2016), who distinguishes competition from cooperative competition; fourthly, the legitimization conditions of the competition in the competences acquisition process are established: the competition is qualified when it is ludic, unprepared, authentic, social-cooperative, communicative, meaningful and ethical; and, lastly, the balance mechanisms that guarantee the qualification are established. The second postulate inquires about the thematic selection and integration of contents (Kramsch, 1993; Kumaravadivelu, 2003; López, 2008) through the structuring of the ludic and curricular axes (Fernández, 1997). The third postulate analyzes the possibilities and the sense of incorporating the iterative cycles to the learning process. The fourth postulate identifies the distinctive features between Teaching Object and CA device through the operations that ensure their integrated modularity. The third an 
fourth postulates are conceived to solve the text book weaknesses detected by Santamaría (2008) and Ezeiza (2009).

\section{Methodology}

The parameterization of the VIQTORIA postulates and the SCP and LP constructs in the diagnostic tool give this work a quantitative outlook. However, it is part of a larger, mainly qualitative project, where the characterization of these postulates in the systems prevail, and emerging categories are grouped.

\subsection{Composition of the corpus: the five criteria involved and the systems selected}

The corpus is composed by a selection of systems used in the teaching-learning processes of SFL for the development of the pluricultural competence in an immersion context. Due to the heterogeneity of the offer and the absence of conclusive and recent literature that define the kind of products, and how many and which are the paradigmatic ones, it is essential to establish five criteria for their analysis and categorization: pedagogic sufficiency, specificity, ubiquity, innovation and autonomy of use.

The pedagogic sufficiency establishes the distinction between system and resource. A system possesses pedagogic sufficiency when it includes all the essential components of a syllabus explicitly or implicitly (objectives, contents, methodology and evaluation). A resource, however, possesses an accessorial character and lacks one or more essential components of the systems designed to conduct the teaching-learning process. Following the resource classification in Arrarte (2011), the resources for the communication and virtual communities (e-mail, Internet forums, blogs, podcasts, social media, etc.) are not considered systems, neither the didactic resources in SFL of the Cervantes Virtual Center (Centro Virtual Cervantes) nor other resources of general nature, such as dictionaries or search engines. In the same way, diverse existing tools for the incorporation of gamification elements, such as Kahoot or Classbadges, do not enjoy pedagogic sufficiency either.

The systems are categorized through an axis of cartesian coordinates divided into four quadrants. On the horizontal axis, the systems are classified according to the autonomy of use, that is, if by design it places the student in an independent or collective activity, guided by a teacher. On the vertical axis, they are arranged according to their level of innovation. The systems are classified as conservative, when there is a transfer of the traditional teaching-learning processes to the digital environment, or as transformative when predominate interactions and processes originally created for a digital environment hardly reproducible outside of it.

In this way, the most conservative and less autonomous systems are called Editorial Products (hereinafter, EP); and the most transformative and autonomous, Applications 
(hereinafter, APP). Regarding the frequency of use or ubiquity, the EP are selected according to the data sent by the editorials about the systems with greater distribution: Aula internacional (Difusión); Español en marcha (SGEL); Generación 3.0 (enClave ELE); Nuevo prisma (Edinumen); Vente (EDELSA). The APP are selected according to the number of downloads shown on the Google Playstore: Duolingo (more than 50 million downloads); Babbel (more than 10 million); Busuu (more than 10 million); Memrise (more than 10 million); Rosetta stone (more than 5 million).

The fact that the sample was restricted to these categories (EP and APP) doesn't deny the existence of other types of systems that meet the criterion of pedagogic sufficiency: Learning Management System, Gamified Learning Systems o Massive Online Open Course. Although they allow the construction of complete syllabuses of any discipline, this versatility implies a lack of contents, activities, and so on. They have the capacity to contain a hypothetical product, but they are not valid to evaluate any concrete content as a part that belongs to the system from scratch. Thus, this restriction is justified by the criterion of specificity, which defines the set of systems created especially for SFL.

\subsection{The data collection tool: the improvement of the template}

The template is used to analyzed the fulfillment of the postulates of the didactic action model in the print and digital systems that compose the corpus. In this work, we applied the 1.1 version of the template, codified in Excel, that resulted from the validation and piloting process of the 1.0 version, developed in QuestionPro. The main findings that motivated this change stand out the substitution of a sequential codification (each system independently) by a simultaneous codification (which favors the comparison between systems); the integration of the data codification and interpretation that avoid a later data treatment; the greater ease of movement between sections and the modification of the entered values; and the simplification of the original design by the removal of conditional itineraries, which facilitates future iterative processes of refining the template. Another significant change is the substitution of a dichotomous scale (with two possible states: compliance or noncompliance, $v=\{0,1\})$ by a scale of three values $(v=\{0,1,2\}$, where 0 means the noncompliance or absence of the parameter; 1 means the insufficient compliance with what is prescribed by the VIQTORIA model; and 2 means the compliance according to what is postulated in the VIQTORIA model).

Regarding its structure, version 1.1 operates as a spreadsheet in Excel. The constructs SCP and LP are encoded on different sheets. Each postulate has its own sheet, except the qualified competition, which is divided into four sheets: three for the events that are inherent in it plus a fourth one with the balance mechanisms. Another sheet is devoted to the universal features that affect all postulates globally. 


\section{Analysis of results: VIQTORIA model, SCP and LP in SFL learning systems}

The results of the application of the template to the corpus are presented according to the postulates of the model. As shown in table 1 and table 2, in global terms, the EP and the APP systems obtain a low average (0,41 and 0,31, respectively).

Table 1. Compliance with the postulates of the VIQTORIA model and the SCP and LP constructs in the systems grouped as APP category.

\begin{tabular}{|c|c|c|c|c|c|c|c|}
\hline Postulates & $\begin{array}{c}\text { Learning } \\
\text { Systems } \\
\text { Average }\end{array}$ & $\begin{array}{l}\text { Media } \\
\text { EP }\end{array}$ & $\begin{array}{c}\text { APP1 } \\
\text { Duolingo }\end{array}$ & $\begin{array}{c}\text { APP2 } \\
\text { Babbel }\end{array}$ & $\begin{array}{c}\text { APP3 } \\
\text { Bussuu }\end{array}$ & $\begin{array}{c}\text { APP4 } \\
\text { Memrise }\end{array}$ & $\begin{array}{c}\text { APP5 } \\
\text { Rosetta } \\
\text { Stone }\end{array}$ \\
\hline $\begin{array}{c}\text { Qualified } \\
\text { Competition }\end{array}$ & 0,35 & 0,24 & 0,33 & 0,20 & 0,25 & 0,33 & 0,19 \\
\hline Thematic Core & 0,45 & 0,44 & 0,48 & 0,33 & 0,42 & 0,53 & 0,44 \\
\hline $\begin{array}{l}\text { Didactic } \\
\text { Iteration }\end{array}$ & 0,19 & 0,29 & 0,53 & 0,00 & 0,00 & 0,53 & 0,39 \\
\hline $\begin{array}{c}\text { DAC } \\
\text { Operationa- } \\
\text { lization }\end{array}$ & 0,32 & 0,29 & 0,34 & 0,22 & 0,28 & 0,38 & 0,25 \\
\hline Global & 0,49 & 0,45 & 0,52 & 0,36 & 0,46 & 0,51 & 0,41 \\
\hline VIQTORIA & 0,36 & 0,34 & 0,44 & 0,22 & 0,28 & 0,45 & 0,34 \\
\hline SCP & 0,11 & 0,08 & 0,00 & 0,00 & 0,00 & 0,40 & 0,00 \\
\hline PL & 0,63 & 0,60 & 0,67 & 0,50 & 0,67 & 0,67 & 0,50 \\
\hline Constructs & 0,37 & 0,34 & 0,33 & 0,25 & 0,33 & 0,53 & 0,25 \\
\hline Average & 0,36 & 0,31 & 0,38 & 0,22 & 0,28 & 0,43 & 0,27 \\
\hline
\end{tabular}

The mean of all the systems shows that only the Linguistic Posture $(0,63)$ exceeds 0,5 points. This is consistent with the attention traditionally given to the linguistic over the sociocultural. The most abundant constructs among the APP are the ones already mentioned LP $(0,60)$, the universal parameters $(0,45)$ and the structuring of the thematic core $(0,44)$.

Notable among the EP (table 2) are the LP $(0,67)$, the global parameters $(0,53)$, the qualified competition $(0,45)$ and the structuring of the thematic core $(0,45)$. On the other hand, the equilibrium mechanisms ( 0 on both categories), the SCP $(0,08$ in the APP, 0,14 in 
the EP) and the iteration $(0,29$ and 0,1 for an overall average value of 0,19$)$ were left behind.

Table 2. Compliance with the postulates of the VIQTORIA model in the systems grouped as EP category.

\begin{tabular}{cccccccc}
\hline Postulates & $\begin{array}{c}\text { Learning } \\
\text { Systems } \\
\text { Average }\end{array}$ & $\begin{array}{c}\text { Media } \\
\text { EP }\end{array}$ & $\begin{array}{c}\text { EP1 } \\
\text { Aula } \\
\text { Interna- } \\
\text { cional }\end{array}$ & $\begin{array}{c}\text { EP2 } \\
\text { Español } \\
\text { en } \\
\text { marcha }\end{array}$ & $\begin{array}{c}\text { EP3 } \\
\text { Genera- } \\
\text { ción 3.0 }\end{array}$ & $\begin{array}{c}\text { EP4 } \\
\text { Nuevo } \\
\text { Prisma }\end{array}$ & $\begin{array}{c}\text { EP5 } \\
\text { Vente }\end{array}$ \\
\hline $\begin{array}{c}\text { Qualified } \\
\text { Competition }\end{array}$ & 0,35 & 0,45 & 0,48 & 0,47 & 0,52 & 0,37 & 0,44 \\
$\begin{array}{c}\text { Thematic Core } \\
\text { Didactic Iteration }\end{array}$ & 0,45 & 0,45 & 0,45 & 0,44 & 0,50 & 0,43 & 0,43 \\
$\begin{array}{c}\text { DAC } \\
\text { Operationalization }\end{array}$ & 0,19 & 0,10 & 0,00 & 0,00 & 0,50 & 0,00 & 0,00 \\
Global & 0,49 & 0,53 & 0,55 & 0,55 & 0,68 & 0,40 & 0,50 \\
VIQTORIA & 0,36 & 0,38 & 0,37 & 0,36 & 0,53 & 0,30 & 0,34 \\
SCP & 0,11 & 0,14 & 0,30 & 0,00 & 0,00 & 0,40 & 0,00 \\
PL & 0,63 & 0,67 & 0,67 & 0,67 & 0,67 & 0,67 & 0,67 \\
Constructs & 0,37 & 0,40 & 0,48 & 0,33 & 0,33 & 0,53 & 0,33 \\
\hline Average & 0,36 & 0,41 & 0,43 & 0,39 & 0,49 & 0,37 & 0,38 \\
\hline & & Source: & $0 w n$ elaboration & & 0,34 & \\
\hline
\end{tabular}

Source: Own elaboration.

In Figure 1, the most prominent APP are Memrise (0.43 - APP4) and Duolingo (0.38 APP1), which are the most gamified ones. Among the EP, stand Aula Internacional out (0, 43 - PE1) and, especially, Generación 3.0 (0,48 - PE3). Generación 3.0 is as well the EP that has the most advanced gamification. 


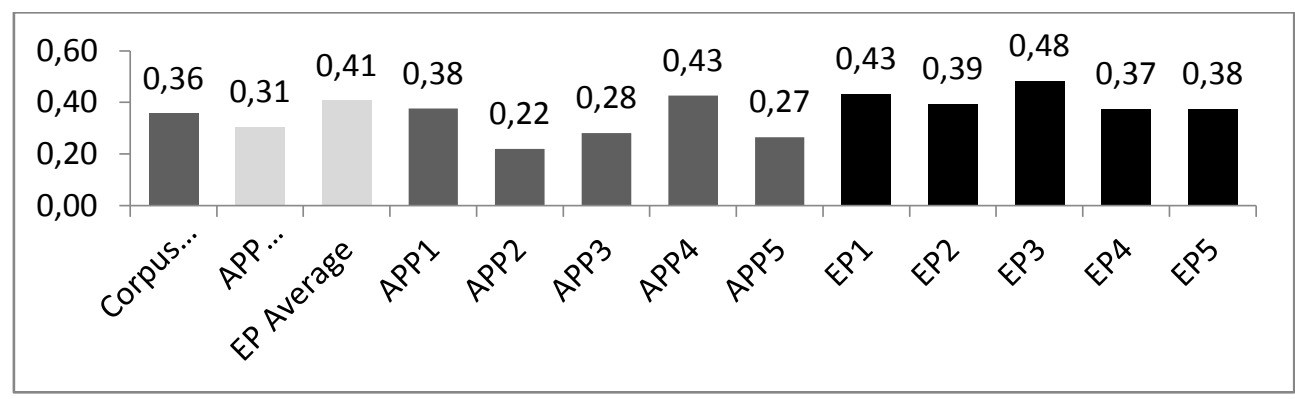

Figure 1. Performance of the complete corpus, of the APP and EP categories and of each system in compliance with the VIQTORIA model and the SCP and LP constructs. Source: Own elaboration.

Figure 2 offers an eloquent graphic representation about the scores obtained by the parameters according to the categories APP and EP, thus facilitating the perception of contrasts. The iteration is the only postulate in which the APP obtain a better score than the EP $(0,19$ difference). The structuring of the thematic core is the postulate in so much as there is a smaller distance in favor of the EP $(0,44$ and 0,45$)$ and the qualified competition is the one with a greater difference (0,21 separate APP and EP). However, in the overall calculation of the VIQTORIA model, the difference between APP (0.34) and EP (0.38) is only 0.04 .

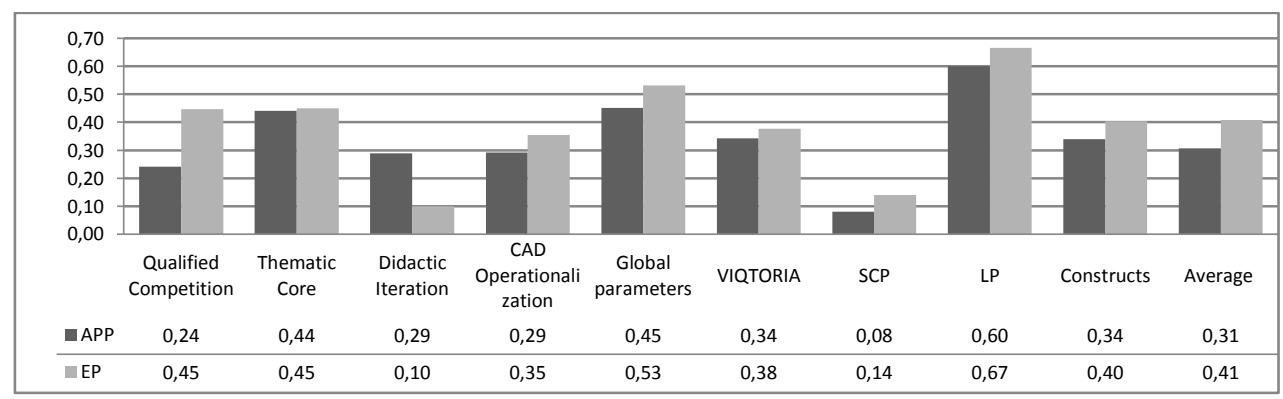

Figure 2. Performance of the APP and EP categories in compliance with the VIQTORIA model and the SCP and LP constructs. Source: Own elaboration.

\section{Conclusions}

The VIQTORIA model tries to put forward an enriched vision that abandons the traditional teaching-learning coordinates and advocates opening the frame of understanding to establish as a reference the competition-acquisition pair, that refers to how (by competing) and why (to acquire competencies). The results show that the systems analyzed do not comply with this approach. 
In summary, the results manifest a considerable improvement margin. Even more if we consider that the score range is not from 0 to 1 , but from 0 to 2 . In this sense, the nature of the digital systems supposes a mitigator. The provisional nature of the results is recognized as it is a set of dynamic products, in permanent development process, and this capability of improvement, which in a sense means a limitation for the research, paradoxically manifests one of the most attractive characteristics of these new resources: its greatest potential lies in the possibility of creating original digital modes, going beyond their adaptation to a digital environment.

To close, we propose a final reflection that highlights the insoluble relationship of the VIQTORIA model and the competition-acquisition process, derived from a shared genesis in this research. The acquisition of competences is a complex, dynamic and multimodal process that includes, but also exceeds, certain pedagogic visions. Rethinking the acquisition of competencies as a qualified competitive act allows us the integration of a series of characteristics (ethical, ludic, social-cooperative, communicative, unthinkable and authentic) as a condition of its legitimation.

\section{References}

Arrarte, G. (2011). Las tecnologías de la información en la enseñanza del español. Madrid: Arco.

Cantador, I. (2016). La competición como mecánica de gamificación en el aula: Una experiencia aplicando aprendizaje basado en problemas y aprendizaje cooperativo. In R. Contreras (ed.), Gamificación en aulas universitarias (pp. 68-97). Barcelona: Instituto de la Comunicación de la Universidad Autónoma de Barcelona.

Council of Europe. (2001). Common European framework of reference for languages: Learning, teaching, assessment. Cambridge: Press Syndicate of the University of Cambridge.

Deutsch, M. (1949). A theory of cooperation and competition. Human Relations, 2(2), 129152.

Ezeiza, J. (2009). Analizar y comprender los materiales de enseñanza en perspectiva profesional: algunas claves para la formación del profesorado. Marco ELE, 9, 1-58.

Fernández, S. (1997). Aprender como juego. Juegos para aprender español. Las actividades lúdicas en la enseñanza de ELE. Carabela, 41, 7-22.

Fulu, I. (2007). Enhancing Learning through Competitions. London: School of InfoComm Technology, Ngee Ann Polytechnic.

Holgueras, A. (2017a). Postura lingüística y estrategias de aprendizaje en escolares en contexto de inmersión bajo el Currículo Nacional Británico. Revista Nebrija de Lingüística Aplicada, 22.

Holgueras, A. (2017b). Proximidad sociocultural y postura lingüística en escolares en contexto de inmersión en Málaga y propuesta de mejora: el modelo de acción didáctica VIQTORIA (Tesis doctoral). 
Jiménez, F. (2012). Análisis estructural y funcional de los juegos colectivos. Santa Cruz de Tenerife: Universidad de La Laguna.

Kramsch, C. (1993). Context and culture in language teaching. Oxford: Oxford University Press.

Kumaravadivelu, B. (2003). Beyond methods. Macrostrategies for language teaching. New Haven: Yale University Press.

López, M. (2008). La integración de lengua y contenidos en EL2 en el ámbito escolar: modelos e implicaciones. In Actas del XVIII Congreso de ASELE. ELE: enfoque comunicativo y gramática. La evaluación en el aprendizaje y la enseñanza del Español como Lengua Extranjera / Segunda Lengua, 370-378.

Ryle, G. (1949). The Concept of Mind. Chicago: The University of Chicago Press.

Santamaría, R. (2008). La competencia sociocultural en el aula de español L2/LE: una propuesta didáctica (Doctoral dissertation).

Shindler, J. (2009). Transformative classroom management: Positive strategies to engage all students and promote a psychology of success. London: John Wiley \& Sons.

Thiess, G., Tschiene, P. \& Nickel, H. (2004). Teoría y metodología de la competición deportiva. Barcelona: Paidotribo. 